CZU:821.135.1.09

https://doi.org/10.52505/llf.2021.1.12

\title{
MIHAI CIMPOI DESPRE RADU PETRESCU: SCRIITURA CA ACT EXISTENȚIAL
}

\author{
Galina ANIȚOI \\ Institutul de Filologie Română „Bogdan Petriceicu-Hasdeu” \\ ORCID: https://orcid.org/0000-0002-3166-1472
}

Răspunzând „preocupărilor pentru promovarea valorilor în spiritul continuității”, studiul-eseu al lui Mihai Cimpoi Radu Petrescu flaubertianul postmodern (Târgoviște, Ed. Bibliotheca, 2019) este o contribuție importantă la valorificarea operei lui Radu Petrescu, prozator și diarist, unul dintre precursorii școlii postmoderniste românești.

Mihai Cimpoi pune în lumină activitatea literară a lui Radu Petrescu, fondatorul Școlii de la Târgoviște, și predilecția acestuia pentru metaliteratură. Descoperim, astfel, imaginea unui scriitor complex, de formație flaubertiană, ilustrând „momentul de răscruce în evoluția literaturii române, când romanele încep să vorbească despre romane, despre modul de a reprezenta și a da formă și sens experienței”.

Din studiul lui Mihai Cimpoi aflăm/ ne amintim că Radu Petrescu a creat prin spectrul lui Flaubert. Doar că Flaubert nu apare, subliniază academicianul, ca un obișnuit autor-model, care, așa cum se spune în mod curent, a avut o influență binefăcătoare. E vorba, în cazul lui Radu Petrescu, de ceva mult mai mult, de un complex Flaubert „care-i acaparează total ființa, înrobind-o”, de ceva "ținând de un act absolut spontan și suveran al subconștientului". Scriitura devine pentru el un act existențial și în acest raport literatură - viață, Radu Petrescu impune ecuația autoritară Lumea -Text. Foarte preocupat de stil, asupra căruia lucra foarte mult, „cu o îndărătnicie fanatică și devotată”, precizează dl Cimpoi, nu-l interesa produsul finit, ci procesul operei, adică 
tot ce ține de construcția textului, de tehnica prin care se generează efectul artistic: „Opera (romanul, jurnalul)”, personajul literar se scrie și se re-scrie, se frazează și se parafrazează, se construiesc și se de-construiesc, se figurează și se des-figurează (cu permanente ștersături cu acizi, spune chiar autorul) într-o frenezie bovarică a nemulțumirii/respingerii a ceea ce prinde contur material, fenomenologic de operă sau personaj, adică de ficțiune beletristică.” (p. 26) Tot ce scrie Radu Petrescu, autoizolat ca și Flaubert, este pentru el însuși, singurul destinatar al textului.

Cercetătorul Mihai Cimpoi mai observă că pattern-ul se manifestă și prin obișnuința de a reciti. Ca un adevărat emul, scriitorul târgoviștean recitește, cu aceeași febrilitate cu care rescrie, pentru a verifica condiția stilistică a textului. La aceasta se adaugă corectura cu demonia ei. Așadar, pentru Radu Petrescu, concluzionează dl Cimpoi, „modelul de stil flaubertian este, eminamente, un model de perfecțiune”.

În cartea de față este pusă în discuție și modernitatea care apare la Radu Petrescu ca o pasiune de cunoaștere. Prin grila modernității, înțeleasă ca tip de mentalitate, ca model de existență, el înțelege lumea, se înțelege pe sine și înțelege cum să scrie. Consideră, lucru pe care îl mărturisește în unele scrieri ale sale, că tipul omului modern îl poate reprezenta cel mai bine adolescentul. „Marea temă a lui Radu Petrescu, afirmă Mihai Cimpoi, este adolescențta, ca singura vârstă care merită toată atenția și prozele sale se impun ca portrete fiziologice de adolescenți surprinși mai cu seamă prin prisma contrastelor, conform acelei contradicții de tip nihilism/ entuziasm, ca bildings romane" (p. 45).

Un alt compartiment al volumului la care facem referinţă este dedicat și activității de diarist a lui Radu Petrescu. În paragrafele „O po(i)etică a jurnalului?” și „Diaristul absolut”, în viziunea lui Eugen Simion, sunt abordate particularitățile jurnalului radupetrescian: paratextualitatea, „în sensul că totul se „organizează”, în temeiul legăturilor cu care intră textul cu alte texte, al relațiilor cu cei din jur, al contactelor empatice sau antipatice cu autorii cărților pe care îi citește, al raporturilor „,intime” care se stabilesc cu propriul text, $\mathrm{cu}$ Sinele său”, constelarea „de imagini, de figuri, de notații, de întâmplări, amintiri, reflecții, de înrudiri”, preocuparea pentru compoziție percepută ca întreg.

Mihai Cimpoi susține că Jurnalul lui Radu Petrescu se axează pe o permanentă autoscopie, iar prin neîntrerupta consemnare a lecturilor Jurnalul urmărește și obiectivul unei permanente automodelări, a unei continue ars poetica.

Tot aici sunt analizate portretul pe care i-l consacră Eugen Simion lui Radu 
Petrescu în Scriitori români de azi (IV, 1989) și amplul capitol cu o privire specială asupra Jurnalului în Ficțiunea jurnalului intim (2001; 2018). Academicianul român face referință la destinul ciudat al scriitorului târgoviștean, ciudățenie pe care dl Mihai Cimpoi, academicianul nostru, o explică prin faptul că Radu Petrescu „s-a dorit un flaubertian, un artist - adică - pentru care o frază valorează mai mult decât conturarea unui personaj și pentru care problema fundamentală este stilul, prin izolarea totală de viața literară, el tipărind-și cărțile cu mult mai târziu decât când le-a scris, prin faptul că operele sale cele mai bune sunt... jurnalele acestor opere și nu operele de ficțiune propriu-zise” (p. 100).

În paragraful Bacovia, poet al infernului dantesc, Mihai Cimpoi ne oferă detalii curioase despre teza de licență a lui Radu Petrescu. Susținută la 6 februarie 1970, lucrarea ne dezvăluie, potrivit cercetătorului nostru, „un Bacovia totalmente radupetrescian".

Secțiunea finală a cărții, intitulată Radu Petrescu prin el însuși și prin alții, întregește imaginea scriitorului Radu Petrescu, care se constituie, în opinia autorului acestei cărți, din „numeroase automărturisiri care se transformă într-un referențial auctorial continuu ce se dezvăluie prin confesiuni directe sau prin identificări cu personajele din Jurnal, din romane, din mărturiile contemporanilor, (...), și, bineînțeles, din aprecierea criticilor făcute în cronicile de întâmpinare la operele editate, în istorii și dicționare literare, în studii monografice despre jurnal (cel al lui Eugen Simion asupra diarismului românesc, fiind unul de referință), în monografiile ce i s-au consacrat aparte sau școlii și în panoramările receptării”. Astfel, Mihai Cimpoi constată: „Din autoportretul pe care și-l face în Jurnal și din materialele critice care s-au scris despre operele lui, Radu Petrescu se conturează ca un Om al Cărții, ca un Om care are o viziune borgesiană asupra Universului ca bibliotecă. E un Om-Carte, în această ecuație identificarea făcându-se sub semnul Absolutului” (p. 121).

În concluzie, prin volumul Radu Petrescu flaubertianul postmodern, Mihai Cimpoi ne îndeamnă la (re)lectura operei lui Radu Petrescu, scriitorul târgoviștean - un destin ciudat - peste care s-a așezat, pe nedrept, „un val al neînțelegerii”.

Notă. Cronica a fost realizată în cadrul proiectului de cercetare 20.80009.1606.03 Contexte socio-culturale autohtone și interconexiuni europene în creația populară și literatura cultă din Basarabia (sec. XIX până în prezent), Institutul de Filologie Română „Bogdan Petriceicu-Hasdeu” al MECC. 